\title{
PERAN MANAJEMEN PERUBAHAN PADA AKUNTANSI MANAJEMEN STRATEGIS AKIBAT VIRUS CORONA
}

\author{
${ }^{1}$ Lesi Hertati, ${ }^{2}$ Apriapollo Syafarudin ${ }^{3}$ Otniel Safkaur \\ ${ }^{1}$ Economics of Accounting, STIE Rahmaniyah Sekayu \\ ${ }^{2}$ Faculty of Economics and Business, Mercu Buana University, DKI Jakarta \\ 3Faculty Economics of Accounting University Cendrawasih Papua \\ Email: hertatilesi@yahoo.co.id
}

\begin{abstract}
Perubahan pola hidup akibat virus Corona atau Covid-19 berdampak keseriusan kesehatan masyarakat dan manajemen perubahan hidup yang mengancam stabilitas ekonomi. Beberapa perusahaan sudah melakukan efisiensi, mulai dari memotong gaji hingga memutuskan Penghentian Hubungan Kerja (PHK). Kondisi ekonomi rumah tangga berdampak serius pada masyarakat kalangan menengah kebawah yang harus bisa merubah pola hidup atau kebiasaan buruk belanja hal yang tidak penting namun ada beberapa strategi manajemen hidup yang harus kita lakukan agar bisa bertahan hidup dimasa sulit yaitu mengatur strategi manajemen pengeluaran agar bisa bertahan hidup dengan ketidakpastian situasi kapan wabah akan berlalu. Memastikan strategi apa yang akan diambil agar aman guna kelangsungan bisnis hidup kedepannya. Diketahui dimana titik-titik kritis dalam rantai pasokan, menyiapkan cadangan darurat saat persediaan menipis dan mengidentifikasi pasokan alternatif termasuk dalam perencanaan darurat ini. Pastikan juga karyawan-karyawan yang berada di posisi krusial untuk mendukung bisnis perusahaan tetap dapat bekerja dengan fleksibilitas tinggi melalui kebijakan work from home dan remote meeting. Sebab jika kerja sama antara pemerintah dengan masyarakat yang memiliki bisnis yang saling menguntungkan hal ini akan menghindari adanya penurunan dan kerugian akibat dampak dari virus corona yang memberi efek tidak baik terhadap perekonomian keluarga. Metode penelitian ini adalah metode deskriptif dan verifikasi, alat analisisnya adalah pemodelan persamaan struktural (SEM, Lisrel). Hasil penelitian menunjukkan bahwa peran manajemen perubahan pada akuntansi manajemen strategis akibat virus corona cukup berpengruh.
\end{abstract}

Keyword: Manajemen Perubahan, Akuntansi Manajemen Strategis

\section{THE ROLE OF CHANGE MANAGEMENT IN STRATEGIC MANAGEMENT ACCOUNTING DUE TO CORONA VIRUS}

\begin{abstract}
Changes in lifestyle due to the Corona or Covid-19 virus impact the seriousness of public health and management of life changes that threaten economic stability. Some companies have made efficiencies, starting from cutting salaries to terminating employment terminations. Household economic conditions have a serious impact on people in the middle class who must be able to change their lifestyle or bad shopping habits that are not important, but there are some life management strategies that we have to do in order to survive difficult times, which is to manage spending management strategies in order to survive with uncertainty as to when the plague will pass. Ensure what strategies will be taken so that they are safe for future business survival. It is known where critical points in the supply chain are, preparing emergency reserves when supplies run low and identifying alternative supplies included in this emergency planning. Also make sure employees who are in a crucial position to support the company's business can still work with high flexibility through work from home and remote meeting policies. Because if the cooperation between the government and the community that has a mutually beneficial business this will avoid the decline and losses due to the impact of the corona virus which gives a bad effect on the family economy. This research method is descriptive and verification
\end{abstract}


I-FINANCE: a Research Journal on Islamic Finance Vol.06 No. 02 Desember 2020 http://jurnal.radenfatah.ac.id/index.php/I-Finance

Lesi Hartati, Apriapollo Syafarudin, Otniel Safkaur...Peran Manajemen Perubahan

method, the analytical tool is structural equation modeling (SEM, Lisrel). The results showed that the role of change management in strategic management accounting due to corona virus is quite influential.

Keyword: Change Management, Strategic Management Accounting

\section{PENDAHULUAN}

Awal tahun 2020 dunia diguncang masalah wabah pademik covid-19 yang cukup viral sehingga berdampak lansung pada sektor ekonomi yang melanda kawasan Asia termasuk Indonesia. Perekonomian Asia pada tahun 2020 pengalami penurunan yang mengarah kepada pendapatan dan terjadi pemutusan hubungan kerja dimana-mana sehingga tingkat ekonomi rakyat semakin sulit (Lachmann, et, all, 2013). Negara-negara industri seperti Korea, Taiwan, Singapura dan terutama China yang pertama kali terkena dampak Covid-19 dan menular kesemua penduduk diseluruh dunia harus lock down agar virus tidak menular dengan cepat. Sektor pariwisata yang paling utama terkena dampak kemudian merambak ke sektor industri di Asia yang memberikan pengaruh secara signifikan terhadap liberalisasi perdagangan di seluruh Asia. Keadaan ini menyebabkan dunia bisnis di Asia menjadi menurun termasuk di Indonesia (Mejer, Carsten.2004.). Dalam menghadapi manajemen perubahan tersebut perusahaan manufaktur di Indonesia seperti pariwisata, hotel, restoran dan penerbangan yang cukup terdampak dihadapkan pada tantangan berat untuk mempertahankan pangsa pasar, mengingat pukulan virus Corona begitu besar pengaruhnya terhadap semua penduduk di seluruh dunia sehingga pangsa pasar global dari waktu ke waktu mengalami penurunan.

Fenomena alam menyebabkan menurunan tingkat ekonomi masyarakat diseluruh dunia disebabkan situasi Corona yang mengancam nyawa manusia yang tertular lewat sentuhan. Indonesia diproyeksikan pada tahun 2021 baru bisa keluar dari kesulitan ekonomi disebabkan gangguan alamiah. Virus Corona yang menyebabkan penyakit COVID-19 telah menyebar hingga lebih dari 80 negara, pandemi virus Corona hingga saat ini telah mencapai lebih dari 334 ribu kasus di seluruh dunia. Virus Corona diduga berasal dari sebuah pasar hewan yang ada di Wuhan, China. Virus Corona merupakan penyakit zoonosis, yakni penyakit yang ditularkan antara hewan dan manusia. mengenai hubungan antara kelelawar dan virus Corona Centers for Disease Control and Prevention (CDC) di Amerika (2020). Faktor penyebab penurunan ekonomi sehingga menyebabkan manajemen kehidupan ikut berubah di antaranya: (1) Melemahnya pasar ekspor, berdampak pada menyempitnya pasar, selanjutnya mengakibatkan pendapataan sales semakin mengecil, dan didorong oleh pendapatan masyarakat tidak ada serta komponen pemasukan dari pekerjaan Nol disebabkan banyaknya pemutusan hubungan kerja yang menyebabkan banyaknya pengagguran masal, (2) Lemahnya penguasaan teknologi, yang membuat industri manufaktur ini akan semakin melemah; (3) Rendahnya kualitas SDM sebagaimana tercermin dari tingkat pendidikan tenaga kerja industri; (4) Belum terintegrasinya UKM di Indonesia dalam satu mata rantai pertambahan nilai dengan industri skala besar; (5) 
Kurang sehatnya iklim akibat di porak-porakan Corona karena banyak subsektor industri yang beroperasi gulung tikar dalam kondisi bangkrut (BPS, 2019).

Fenomena lain yang dikatakan oleh OECD (2020) adalah faktor penyebab menurunnya ekonomi rakyat pada industri manufaktur dan UMKM yaitu: (1) Ketidakmampuan untuk mengukur, mengevaluasi dan mengelola perubahan alam akibat wabah covid-19 sehingga menyebabkan perubahan didalam manajemen keluarga. Keadaan ini menyebabkan timbulnya penggangguran masal sumberdaya secara cukup drastis; (2) Perubahan manajemen hidup diakibatkan tidak bekerja didalam jangka panjang yang tidak bisa diprediksi kapan berakhirnya Corona yang tidak terselesaikan sehingga menimbulkan kesulitan dalam membangun kelompok kerja yang efektif, yang pada akhirnya menyebabkan kesulitanekonomi di dalam keluarga dan perusahaan; Keadaan ini menimbulkan iklim kerja yang tidak kondusif; (6) Inefisiensi di dalam pengelolaan perubahan manajemen keluarga sehingga mau tidak mau penghematan pengeluaran agar bisa bertahan hidup, sehingga menyebabkan adanya waktu tunggu atau penundaan produksi.

Faktor lain yang dapat mempengaruhi trategi pasar dan fungsi akuntansi yaitu manajemen perubahan (Shank, and Vijay. 1992). Sejalan dengan hal itu Bhimani (2002) mengemukakan bahwa manajemen perubahan dapat mempengaruhi strategi akuntansi manajemen. Didukung oleh studi yang dilakukan oleh Malmi, (2010) menunjukkan bahwa faktor penentu kesuksesan dari akuntansi manajemen strategi salah satunya adalah manajemen perubahan. Studi yang dilakukan oleh Bromwich, (1990) menunjukkan bahwa manajemen perubahan mempunyai pengaruh terhadap kesuksesan sistem ERP (aplikasi sistem informasi akuntansi).

Menurut Bromwich, (1992) manajemen perubahan dapat diartikan merencanakan, memulai, merealisasikan, mengendalikan, dan menstabilkan proses perubahan pada perusahaan dan pribadi. Sedangkan perencanaan dan pengelolaan (manajemen) perubahan dapat diukur dengan proses secara sistematis melalui struktur organisasi, orang, dan teknologi untuk mencapai tujuan. Beberapa fenomena yang berhubungan dengan manajemen perubahan dan berkaitan dengan sistem informasi akuntansi manajemn seperti halnya yang dikemukakan Cadez, \&Guilding, (2008). bahwa persoalan perubahan manajemen kerja yang kurang baik sangatlah kompleks, mulai dari masalah mengubah kultur yang tidak terintegritas, tumpang tindih peraturan terkesan sangat lamban dan tidak memiliki sensitivitas terhadap perubahan lingkungan dan tuntutan masyarakat.

Fauziyah (2020) selaku mentri tenaga kerja mengatakan bahwa banyak perusahaan yang akhirnya memutuskan hubungan kerja dengan karyawannya akibat pandemi virus corona. Ada yang terkena Pemutusan Hubungan Kerja (PHK), dirumahkan, bekerja sebagian, dikurangi gajinya, dan semacamnya. Selanjutnya dikemukakan oleh Widodo (2020) selaku presiden republik Indonesia menyatakan bahwa strategi untuk mencegah pemutusan hubungan kerja massal terhadap para pekerja meminta stimulus modal kerja untuk tetap berproduksi sehingga tidak jadi PHK belum ada kebijakan khusus pemerintah untuk menjawab permintaan para pengusaha dalam teleconference dengan gubernur 
seluruh Indonesia, mengumumkan sejumlah strateginya menghadapi gelojak ekonomi akibat virus corona. Program kartu prakerja yang dijanjikannya pada masa kampanye pilpres 2019 diklaim Jokowi bisa menanggulangi risiko tersebut keadaan membuktikan tidak terbukti. Kartu prakerja implementasi kartu prakerja antisipasi para pekerja yang kena PHK, pekerja harian yang kehilangan penghasilan dan pengusaha mikro yang kehilangan omzet.

Pernyataan ini di dukung oleh. Baines, \& Langfield-Smith, (2003) mengatakan bahwa kendala besar yang menyangkut masalah change management dimana para pengguna meninggalkan proses dan kebiasaan lama menjadi proses yang baru. Orientasi berubah disebabkan oleh situasi yang tidak menentu sehingga fungsi akuntansi manajemen yang penyediaan informasi bagi pemakai intern (untuk kepentingan pengambilan keputusan strategik) ke penyediaan informasi. Informasi keuangan dan non keuangan berubah secara tota bagi pihak luar maupun pihak didalam perusahaan berlangsung secara tidak terduga yang disebabkan datangnya wabah covid-19 yang melanda dunia sehingga pola hidup manusia di seuruh dunia ikut berubah secara terus menerus. Pelaporan keuangan dan non keuangan kepada pihak luar maupun pihak didalam organisasi menjadi pendorong utama dalam perancangan sistem akuntansi strategi sehingga menekankan pengeluaran biaya baik pasar maupun keuangan organisasi diwaspadai secara ketat

Abernethy, \& Brownell, (1999) mengungkapkan bahwa proses perubahan aktual untuk penyelidikan secara terperinci bagaimana peran akuntansi manajemen strategis dalam menangi situasi organisasi secara baik. Hasil penenlitian Verbeeten, F. (2010). membuktikan bahwa hambatan atau masalah yang terkait dengan kegagalan dalam proses perubahan dapat dengan mudah diidentifikasi dan diuji, jika manajemen didalam organisasi dapat bekerja dengan baik dan memberikan pemahaman yang lebih besar tentang fenomena strategis yang dapat memberi kontribusis yang bermanfaat bagi orang baik. kebutuhan pemangku kepentingan untuk mendapatkan nilai informasi yang relevan mengenai prospek perusahaan, langkah-langkah non-keuangan mendukung yang mencerminkan strategi perusahaan dan diharapkan untuk meningkatkan keputusan dan kinerja organisasi Burns, \& Scapens (2000) bidang peningkatan daya saing terbesar yang dihadapi oleh organisasiyang diamati terkait dengan tindakan pesaing, pelanggan dengan ekspektasi yang meningkat dalam kaitannya dengan kualitas dan harga, dan kebutuhan untuk mengembangkan produk baru. Oleh karena itu, organisasi yang sukses berubah menuju strategi yang lebih menekankan pada layanan pelanggan dan inovasi produk disebut akuntansi manajemen strategis.

Akuntansi manajemen strategis adalah sebagian perubahan manajemen relevansinya dan kemampuannya untuk mencerminkan kompleksitas lingkungan perusahaan. Kebutuhan akan perubahan manajemen sistem penetapan biaya yang lebih baik yang secara optimal dapat mencerminkan gambaran lengkap mendesak dan oleh karena itu praktik manajemen baru diharapkan muncul. Penelitian Burns\& Vaivio (2001) membuktikan bahwa berbagai upaya telah dilakukan untuk memperkenalkan praktik akuntansi manajemen strategis yang inovatif, seperti Target Costing (TC), yang berada dalam fase dengan laju perubahan di berbagai industri Untuk memperkuat perubahan manajemen 
yang berkembang dalam studi difusi inovasi akuntansi manajemen dengan fokus pada pengembangan pasar. Bahkan, sebagian besar studi tentang implementasi TC, khususnya, telah dilakukan di negara-negara Barat dan negara maju, termasuk Australia dan Indonesia.

Akuntansi manajemen strategik bermanfaat jika mampu berperan dalam membantu manajemen memprediksi konsekuensi perubahan yang mungkin terjadi atas berbagai alternatif tindakan pada berbagai fungsi manajemen seperti perencanaan, pengendalian dan pengambilan keputusan (Chenhall, Langerfield-Smith,1998). Pernyataan Cravens, Guilding, (2001) Akuntansi manajemen strategik berperan dalam meningkatkan kemampuan manajer memahami keadaan lingkungan yang sebenarnya dan mampu mengidentifikasikan aktivitasaktivitas yang relevan dalam lingkungan tersebut.

Kemudian Govindarajan, and John (1992) menyatakan fungsi akuntansi manajemen strategi didlam organisasi adalam untuk perbaikan proses, benchmarking ditujukan untuk memotivasi dan menstimulasi karyawan agar bekerja secara kontinyu untuk memperbaiki kinerja dan memusatkan seluruh energi mereka terhadap pencapaian tujuan perusahaan. Hertati. Syafarudin (2018) menyatakan bahwa perusahaan harus melakukan perbaikan proses yang berkelanjutan agar dicapai kinerja yang lebih baik. Huy, (2001) emyatakan bahwa perbaikan proses yang berkelanjutan tersebut direpresentasikan dalam PDCA Cycle (Plan, Do, Check, and Action Cycle) atau seringkali disebut pula dengan istilah Deming Cycle. Siklus tersebut dirancang untuk membantu manajemen dalam memperbaiki proses dan juga sebagai prosedur untuk mendeteksi akar dari suatu masalah melalui analisis.

Hilton, (2005) and Hoque, (.2001) menyatakan bahwa fungsi akuntansi manajemen startegi diharapkan dapat memberikan masukan kepada karyawan berupa umpan balik untuk mengetahui kesesuaian hasil pekerjaannya dengan tujuan yang ingin dicapai, ternyata menimbulkan perilaku yang menyimpang (dysfunctional behavior). Kasurinen, (1998) and Kaplan, \& Norton, (1996). menyatakan bahwa penyimpangan perilaku tersebut terjadi baik pada prilaku manajemen, berupa tekanan, kemarahan, kecurigaan, ketakutan dan ketidakpercayaan dari pihak pengguna informasi.

Hertati, et, all (2020) manajemen perubahan dapat diartikan merencanakan, memulai, merealisasikan, mengendalikan, dan menstabilkan proses perubahan pada tingkat strategi perusahaan dan pribadi. Senada dengan hal tersebut di atas Macharzina, et,all (.2004) mengatakan bahwa manajemen perubahan merupakan strategi yang diterapkan perusahaan untuk meluaskan dan meningkatkan pemahaman dari sebuah perubahan yang tidak dapat dilakukan secara menyeluruh. Shields, \& Young, (1991) menyatakan bahwa manajemen perubahan adalah alat yang digunakan oleh sumberdaya manusia organisasi untuk melakukan strategis didlam perusahaan agar kinerja organisasi lebih baik. Sejalan dengan hal itu Gurd, \& Thorne, (2003) mengemukakan bahwa manajemen perubahan merupakan proses mengelola (perencanaan, pelaksanaan, pengendalian, dan pengevaluasian) atas perubahan dilihat dari sisi orang dan organisasi untuk mencapai tujuan bisnis yang diinginkan (Change management is the process to manage (planning, implemetation, controling and evaluation) the people and organization side of change to achieve the required business outcome). Pernyataan Nyamori, et, all. 2001: Sulaiman, \& Mitchell,2005: Luther \& Longden, 2001: Lestari \& Hertati, 2020: Lapsley, \& Pallot,2000: Kloot,1997) dalam manajemen perubahan, terdapat empat ukuran yang paling signifikan yaitu:

1. Globalisasi pasar, adalah

Bahwa banyak pasar yang di seluruh dunia dan dilayani oleh perusahaan internasional atau multinasional (Globalization of markets: means that many markets are worldwide and are served by international or multinational corporations) 
I-FINANCE: a Research Journal on Islamic Finance Vol.06 No. 02 Desember 2020 http://jurnal.radenfatah.ac.id/index.php/I-Finance

Lesi Hartati, Apriapollo Syafarudin, Otniel Safkaur...Peran Manajemen Perubahan

2. Teknologi, tehknologi adalah

Informasi (TI) memiliki dampak yang mendalam pada individu karyawan, tim, dan organisasi (Technology: IT is having a profound impact on individual employees, teams, and organizations).

3. Jaringan sosial/ perilaku,adalah

Jaringan sosial memungkinkan karyawan untuk mengabaikan aturan dan mencari solusi untuk memecahkan masalah tanpa melalui rantai organisasi komando (Social networks, social networking allows employees to ignore the rules and find solutions to problems without going through the organization's chain of command).

4. Persaingan,adalah

Kompetisi global, lebih banyak produk dengan lebih banyak fitur dan pilihan, biaya yang lebih rendah, kualitas yang lebih tinggi bersaing (Competition, Global competition, more competing products with more features and options, lower costs, higher quality).

Laitinen, (2001). mengungkapkan bahwa keandalan sistem mengacu pada keandalan dari operasi sistem berjalan (reliability refers to the dependability of system operation). Selanjutnya keyakinan tentang keandalan sistem akan mempengaruhi sikap seseorang atas sistem tersebut yang akan membentuk keyakinan perilaku seseorang tentang cara menggunakan sistem tersebut. Lestari \& Hertati (2020) menyatakan bahwa akuntansi manajemen strategis dapat membantu menyelesaikan pekerjaan berdasarkan data kemudian memproses data guna pengambilan keputusan yang strategis. Kaplan, \& Norton, (1996) and Kloot (1997) mengungkapkan kegunaan akuntansi manajemen strategis adalah dapat membantu manajer untuk memperkirakan situasi dan kondisi yang akan terjadi dimasa yang akan datang, terutama saat melakukan pengambilan keputusan dan menentukan pilihan penting dalam organisasi agar target organisasi bisa tercapai.

Kemudian Lord, (1996) mengungkapkan ketersediaan akuntansi manajemen strategis adalah dapat menentukan biaya dan produksi bagaimana penentu faktor-faktor strategis apa yang akan dipilih. Melalui akuntansi manajemen strategis, mengenai data yang akan dikembangkan yang memungkinkan pengambilan keputusan di tingkat operasional dan strategis sehingga dapat memberi keutungan yang besar bagi organisasi (Pistoni, and Laura 2000: Roslender, Robin and Susan 2003). Adapun ciri-ciri akuntansi manajemen strategi adalah sebagai berikut:

1. Integration adalah

suatu keadaan di mana kelompok-kelompok atau jaringan yang terkoneksi dengan jaringan yang lainya dan bisa beradaptasi secara harmonis terhadap jaringan sistem yang lainya yang dapat memberi informasi yang sama.

2. Flexibilty adalah

Suatu sistem yang dapat digunakan kapanpun dan dimana saja dapat memberi informasi.

3. Reliability adalah

Keandalan adalah suatu penerapan perancangan pada komponen sehingga komponen dapat melaksanakan fungsinya dengan baik. 
I-FINANCE: a Research Journal on Islamic Finance Vol.06 No. 02 Desember 2020 http://jurnal.radenfatah.ac.id/index.php/I-Finance

Lesi Hartati, Apriapollo Syafarudin, Otniel Safkaur...Peran Manajemen Perubahan

\section{Pengaruh Manajemen Perubahan Pada Akuntansi Manajemen Strategis Akibat Virus Corona}

Sementara Gomes, Yasin \& Lisboa, (2007) and Simmonds, (1982) menjelaskan bahwa manajemen perubahan mengacu pada proses untuk meminta, perencanaan, dan pelaksanaan terhadap perubahan sistem informasi (Change management refers to processes for requesting, planning, and implementing change in information systems). Hal yang sama dikemukakan oleh Guilding, and Mike (2000) menyatakan bahwa manajemen perubahan dapat menyediakan metode yang efisien otomatis deteksi, propagasi, dan reaksi yang berdampak terhadap perubahan lingkungan sistem berbasis computer / sistem informasi akuntansi (change management can to provide efficient automated methods of detection, propagation, and reaction to changes in the Large Computer System environment)

Hasil studi yang dilakukan oleh Hassan, (2005) and Simons, (1990) menunjukkan bahwa faktor penentu kesuksesan dari sistem informasi akuntansi salah satunya adalah manajemen perubahan (one of critical success factor of system is change management). Studi yang sama dilakukan oleh Hertati, et, all (2019) and Laitinen, (2006) menunjukkan bahwa penggunaan sistem informasi akuntansi yang diterima dalam perusahaan sebagian besar dipengaruhi oleh majamenen perubahan (the use of Accounting Iinformation System is relatively accepted within accounting firms, which is largely as a effect of the 'change management' that comes with the use of such application).

Penelitian yang senada dilakukan Innes \& Mitchell, (1990) menemukan bahwa faktor penentu kesuksesan sistem adalah manajemen perubahan yang efektif (the most important Critical Sucsess Factors system are effective change management). Hal yang sama dilakukan oleh Burns, \& Vaivio, (2001). memberikan hasil bahwa kurangnya manajemen perubahan sebagai hambatan dari sistem perusahaan untuk keberhasilan pelaksanaan (lack of change management as impediments of enterprise system successful implementation).

Sementara hasil penelitian yang dilakukan oleh Miller, \& Friesen, (1982) and Cadez \& Guilding, (2007) menunjukkan bahwa Ditemukan salah satu faktor penting penentu kesuksesan penerapan sistem sukses adalah program manajemen perubahan (one of critical factor to system implementation success is change management). Weerangsinghe, et, all (1992) and Cadez, \& Guilding (2008) melakukan penelitian yaitu memghasilkan perubahan manajemen dan memandang aturan didlam organisasi tujuannya untuk meningkatkan secara keseluruhan tingkat keberhasilan sistem. Studi yang dilakukan oleh Syafarudi \& Hertati (2020) menunjukkan bahwa manajemen perubahan mempunyai pengaruh dalam menghadapi strategi organisasi guna mencapai perubahan yang lebih baik didalam aplikasi sistem informasi akuntansi manajemen.

Hasil penelitian Cadez, \& Guilding, (2008a) menemukan bahwa akuntansi manajemen strategis adalah alat penganggaran, untuk memisahkan beberapa bagian panting dan mengidentifikasi pusat biaya untuk setiap bagian. Kemudian penenlitian Birkett,(1998) menyimpulkan bahwa kuntansi manajemen strategis dapat menganalisis informasi tentang kinerja, profitabilitas, dan status keuangan keseluruhan biaya didalam organisasi dengan 
menggunakan sistem penetapan biaya yang sesuai (Penetapan Absorpsi Penuh, Penetapan Biaya Marjinal, Penelitian Cravens and Chris (2001) menemukan bahwa penetapan biaya Berbasis Aktivitas, dan Penetapan Biaya Standar) akan menghasilkan identifikasi biaya dan profitabilitas unit- unit yang tepat. Akuntansi manajemen sebagai sistem kontrol manajemen didalam organisasi yang berkontribusi pada penggunaan anggaran sebagai alat peramalan, pencatatan perencanaan dan pengendalian efek lingkungan lembaga pada operasi organisasi. Tujuan utama akuntansi manajemen strategis adalah penetapan biaya yang akurasi pencatatan dan alokasi biaya untuk barang, layanan dan pelanggan.

Penelitian Chenhall, \& Langfield-Smith, (2003) menyatakan bahwa dengan menggunakan alat akuntansi manajerial, elemen-elemen ini akan meningkatkan kualitas arus informasi yang digunakan untuk pengambilan keputusan. Penelitian Feurer, \& Chaharbaghi, (1995) menemukan bahwa proses pengambilan keputusan dikurangi ketika semua perubahan data yang digunakan dalam proses didasarkan pada informasi yang akurat, lengkap, fleksibel, relatif, sederhana, diperiksa ulang. Kemudian Cravens, and Chris (2001) menyimpulkan bahwa strategi didalam manajemen berfungsi agar semua mudah diakses, aman, andal, tepat waktu, dan berbasis nilai. Penelitian Hutaibat (2011) mengemukahkan bahwa penggunaan akuntansi manajemen strategis dianggap mempermudah didalam perubahan manajemen didlam organisasi. Hopwood, (1990) and Cadez, \& Guilding, 2007 menyatakan baha manajemen perubahan diperlukan sebagai alat pelengkap kebutuhan organisasi dalam situasi yang mendadak. Fungsi manajemen dan akuntansi manajemen strategis adalah dapat merasionalisasi biaya terkait dengan alokasi dan transfer informasi dan pengetahuan kepada pembuat keputusan (Chenhall, LangerfieldSmith,1998).

Hipotesis Penelitian:

H1 : Pengaruh Manajemen Perubahan Pada Akuntansi Manajemen Strategis Akibat Virus Corona

\section{Gambar 1: Paradigm Penelitian 2020}

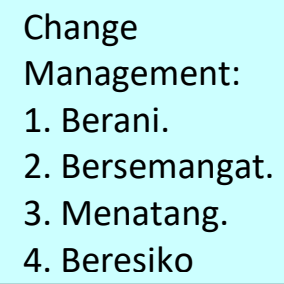

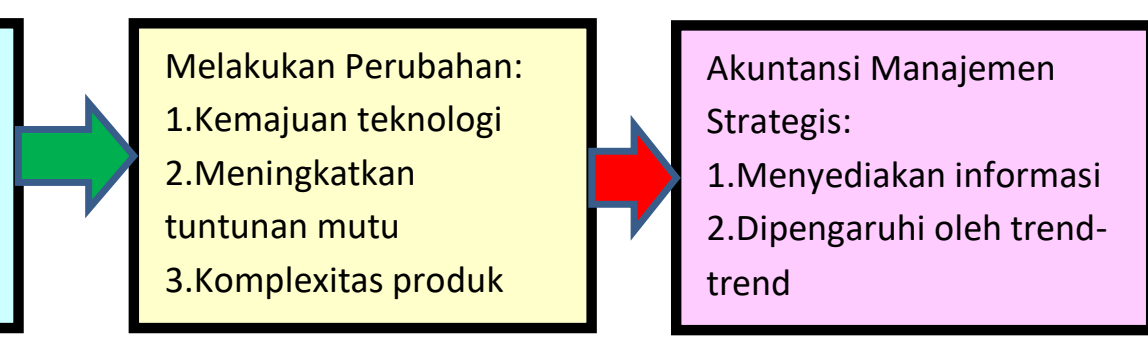

Pengambilan keputusan strategis:

Penyajian laporan keuangan dan non keuangan didalam organisasi dalam situasi yang darurat. 


\section{METODE PENELITIAN}

Populasi target dari penelitian ini adalah usaha kecil dan menengah di Indonesia. Perlu diingat model konseptual yang ditunjukkan pada Gambar 1, instrumen ulasan didirikan dengan memanfaatkan studi sebelumnya. Ciri-ciri hipotesis variabel dirancang menggunakan SEM-Lisrel lima jaaban dari 1 sampai 5. Item pengukuran dari penelitian saat ini terdiri dari dua variabel yang termasuk darurat penemuan ilmiah pengeluaran pemerintah masa covid-19, penurunan angka tenaga kerja.

Populasi yang terdapat dalam penelitian ini berjumlah 4974 orang dan presisi yang ditetapkan atau tingkat signifikansi 0,05 (Sugiyono, 2013). Data penelitian ini dikumpulkan dengan kuesioner melalui google box secara lansung dan mengirim surat kemudian dikumpulkan dari 250 usaha kecil dan menengah di indonesia yang terkait. Setelah mengirim google box pada usaha kecil dan menengah di Indonesia yang terkait secara lansung dengan membagi kuesioner kepada mereka untuk tanggapan mereka.

Proses pemilihan dan usaha kecil dan menengah di indonesia yang terkait sangat penting untuk pengumpulan data bagi peneliti, ketika menyelidiki kreativitas, menekankan pada pusatkan penjualan baik secara online maupun di konter-konter memberikan respons. Karena itu, total 4974 kuesioner dikirimkan dan disebarkan kepada seluruh usaha kecil dan menengah di Indonesia 215 sampel yang merespons. Secara keseluruhan, proses pengumpulan data telah diambil selama 1 bulan dan penelitian ini tidak didanai oleh asosiasi apa pun.

Henri, (2007) menyatakan bahwa untuk mengukur reliabilitas dalam SEM varians) dapat menggunakan composite reliability (reliabilitas konsistensi internal) dan variance exctract measure (ukuran ekstrak varian). Untuk menentukan minimal sampel yang dibutuhkan jika jumlah populasi diketahui, dapat menggunakan rumus Slovin dengan asumsi tingkat kesalahan pengambilan sampel yang ditolerir adalah sebesar 5\%. HolmesSmith, (2005).

Rumus Slovin:

$$
\mathrm{n}=\frac{\mathrm{N}}{1+\mathrm{Ne}^{2}}
$$

Keterangan:

$\mathrm{n}=$ Ukuran Sampel

$\mathrm{N}=$ Ukuran Populasi

$\mathrm{e}=$ Kelonggaran ketidaktelitian karena kesalahan pengambilan sampel yang ditolerir sebesar $5 \%$

Uji validitas dilakukan yang digunakan untuk menentukan kelayakan item dalam daftar pertanyaan untuk menentukan variabel dan uji reliabilitas untuk mengukur keandalan objek yang diukur. Analisis data dilakukan dengan analisis deskriptif dan verifikasi. Analisis deskriptif dilakukan dengan kategorisasi yang seimbang dengan menggunakan rentang kuartil (Sugiyono, 2013). Analisis verifikasi yang digunakan untuk menguji hipotesis dalam 
I-FINANCE: a Research Journal on Islamic Finance Vol.06 No. 02 Desember 2020 http://jurnal.radenfatah.ac.id/index.php/I-Finance

Lesi Hartati, Apriapollo Syafarudin, Otniel Safkaur...Peran Manajemen Perubahan

penelitian ini adalah dengan menggunakan komponen struktural persamaan pemodelan (SEM, Lisrel) atau berbasis varians yang dikenal SEM Lisrel (Allen, \& Seaman, 2007).

\section{HASIL PENELITIAN}

Analisis Deskriptif Globalisasi pasar, Teknologi, Jaringan Sosial, Persaingan akan terungkap melalui jawaban UMKM terhadap pernyataan-pernyataan yang diajukan pada kuesioner. Berdasarkan perhitungan persentase skor jawaban perajin diperoleh hasil seperti tampak dalam tabel berikut ini:

\section{Tabel 1. Hasil Uji Loading factor}

\begin{tabular}{clcccc}
\hline No. & $\begin{array}{c}\text { Loading factor masing- } \\
\text { masing indikator }\end{array}$ & $\begin{array}{c}\text { Globalisasi } \\
\text { Pasar }\end{array}$ & Teknologi & $\begin{array}{c}\text { Jaringan } \\
\text { Sosial }\end{array}$ & Persaingan \\
\hline 1. & Indikator 1 & 0.731 & 0.702 & 0.704 & 0.713 \\
\hline 2. & Indikator 2 & 0.824 & 0.710 & 0.789 & 0.786 \\
\hline 3. & Indikator 3 & 0.856 & 0.592 & 0.762 & 0.648 \\
\hline 4. & Indikator 4 & 0.817 & 0.661 & 0.770 & 0.889 \\
\hline $\mathbf{5 .}$ & Indikator 5 & 0.752 & 0.773 & - & - \\
\hline $\mathbf{6 .}$ & Indikator 6 & 0.471 & 0.584 & - & - \\
\hline 7. & Indikator 7 & - & 0.656 & - & - \\
\hline $\mathbf{8 .}$ & Indikator 8 & - & 0.762 & - & - \\
\hline
\end{tabular}

Sumber: Uji Loading factor, 2020

Berdasarkan hasil perhitungan, nampak bahwa loading factor memiliki nilai lebih dari 0.5 kecuali untuk GP6 (0.471). Oleh sebab itu, GP6 akan dikeluarkan dari model penelitian, kemudian di lakukan uji loading factor revisi.

Tabel 2. Hasil Uji. Loading factor revisi

\begin{tabular}{ccccc}
\hline No. & $\begin{array}{c}\text { Loading factor masing-masing } \\
\text { indikator }\end{array}$ & Integration & Flexibilty & Reliability \\
\hline 1. & Indikator 1 & 0.844 & 0.805 & 0.804 \\
\hline 2. & Indikator 2 & 0.907 & 0.817 & 0.889 \\
\hline 3. & Indikator 3 & 0.908 & 0.805 & 0.862 \\
\hline 4. & Indikator 4 & 0.829 & 0.768 & 0.770 \\
\hline 5. & Indikator 5 & 0.626 & 0.775 & - \\
\hline 6. & Indikator 6 & - & 0.684 & - \\
\hline
\end{tabular}

Sumber: Uji. Loading factor revisi, 2020

Pada tabel loading factor revisi nampak bahwa semua indikator untuk empat variabel di atas 0.5 sehingga dapat dimasukkan dalam model PLS. Covergent validity dari model pengukuran dengan refleksif indikator dinilai berdasarkan korelasi antara item score/component score dengan construc score yang dihitung dengan PLS. Ukuran refleksif individual dikatakan tinggi jika berkorelasi $>0,70$ dengan konstruk yang ingin diukur. 
I-FINANCE: a Research Journal on Islamic Finance Vol.06 No. 02 Desember 2020 http://jurnal.radenfatah.ac.id/index.php/I-Finance

Lesi Hartati, Apriapollo Syafarudin, Otniel Safkaur...Peran Manajemen Perubahan

Tabel 3: Hasil Uji. Hasil Square roots of AVE

\begin{tabular}{|c|c|c|}
\hline $\mathrm{No}$ & Dimensi & Square roots of AVE \\
\hline 1. & Globalisasi pasar & 0.829 \\
\hline & Teknologi & 0.749 \\
\hline 3. & Jaringan Sosial & 0.832 \\
\hline 4. & Persaingan & 0.812 \\
\hline
\end{tabular}

Sumber: Uji. Hasil Square roots of AVE, 2020

Pengujian yang dilakukan dalam inner model dalam menilai model dengan PLS dimulai dengan melihat $\mathrm{R}^{2}$ untuk setiap variabel laten dependen. Perubahan nilai $\mathrm{R}^{2}$ dapat digunakan untuk menilai pengaruh variabel laten independen tertentu terhadap variabel laten dependen apakah mempunyai pengaruh yang substantive.Hasil AVE menunjukkan bahwa indikator yang dimikili oleh masing-masing variabel dapat mengukur variabel yang dimaksud. Discriminat validity adalah membandingkan nilai square root of average variance extracted (AVE) setiap konstruk dengan korelasi antara konstruk dengan konstruk lainnya dalam model. Dimana nilai AVE harus $>0,50$. Hasil composite reliability menunjukkan bahwa masing-masing indikator dapat mengukur variabel dengan andal.

Tabel 4. Hasil Uji Composite Reliability

\begin{tabular}{clcc}
\hline No. & \multicolumn{1}{c}{ Dimensi } & Composite reliability & Cronbach's Alpha \\
\hline 1. & Integration & 0.816 & 0.852 \\
\hline 2. & Flexibilty & 0.810 & 0.866 \\
\hline 3. & Reliability & 0.830 & 0.871 \\
\hline \multicolumn{2}{l}{ Sumber: Uji Composite Reliability, 2020 } & &
\end{tabular}

Composite reliability blok indikator yang mengukur suatu konstruk dapat dievaluasi dengan dua macam ukuran yaitu internal consistency yang dikembangkan oleh Werta, Linn, dan Joreskog dan Cronbach's Alpha. Dimana nilai composite reliability yang baik apabila nilainya $>0,70$.

Tabel 5. Hasil Uji Goodness of fit pada inner model diukur menggunakan $\mathrm{R}$ square

\begin{tabular}{ccc}
\hline No. & Model & R square \\
\hline 1. & Akuntansi Manajemen Strategis Akibat Virus Corona & 0.126 \\
\hline
\end{tabular}

Sumber: Uji Goodness of fit pada inner model diukur menggunakan R square, 2020

Tabel 5 mendeskripsikan bahwa model akhir CFA penurunan angka tenaga kerja yang terbentuk sudah memenuhi beberapa kriteria statistik Goodness of Fit (GOF) seperti $\square$ 2, GFI, AGFI, CFI, TLI atau NFI, RMR, dan RMSEA, sehingga model pengukuran penurunan angka tenaga kerja sudah memenuhi kriteria model pengukuran yang baik (fit) dan dapat dijadikan sebagai manifest bagi pembentukan full model. Model menunjukkan bahwa R-square sebesar 0.126. Hal ini menunjukkan bahwa model memiliki endogen Akuntansi Manajemen Strategis Akibat Virus Corona. 
I-FINANCE: a Research Journal on Islamic Finance Vol.06 No. 02 Desember 2020 http://jurnal.radenfatah.ac.id/index.php/I-Finance

Lesi Hartati, Apriapollo Syafarudin, Otniel Safkaur...Peran Manajemen Perubahan

Tabel 6. Hasil Pengujian Pengaruh langsung

\begin{tabular}{ccccc}
\hline No. & \multicolumn{1}{c}{ Pengaruh Langsung } & Koefisien & Signifikansi & Keterangan \\
\hline 1 & Manajemen Perubahan mempengaruhi & -0.208 & 0.026 & Diterima \\
& Akuntansi Manajemen Strategis Akibat & & & \\
& Virus Corona & & & \\
\hline
\end{tabular}

Sumber: Hasil Pengujian Pengaruh langsung Olah data SPSS, 2020

Berdasarkan hasil perhitungan pengaruh variabel dalam hipotesis pertama, nampak bahwa semakin tinggi keadilan prosedur maka semakin rendah Akuntansi Manajemen Strategis Akibat Virus Corona yang terjadi. Hal ini nampak dari nilai signifikansi 0.026. Oleh sebab itu hipotesis untuk pengaruh langsung dalam variabel ini diterima. Tingkat signifikansi (nilai $\mathrm{p}<0.05$ ) pada taraf di bawah 0.05 menunjukkan bahwa Manajemen Perubahan mempengaruhi Akuntansi Manajemen Strategis Akibat Virus Corona.

Uji reliabilitas dilakukan dengan uji cronbach alpha menggunakan SPSS. Suatu konstruk dikatakan reliabel jika memberikan nilai cronbach alpha $>0,60$. Structural Equation Model (SEM) dengan metode Partial Least Square (PLS) dengan menggunakan software warp PLS 5.0. Metode ini dicetuskan pertama kali oleh Wold sebagai metode umum untuk mengestimasi path model yang menggunakan konstruk laten dengan multiple indikator. PLS merupakan factor indeterminacy metode analisis yang powerful oleh karena tidak mengasumsikan data harus dengan pengukuran skala tertentu dan jumlah sampel kecil (Ghozali, 2014).

\section{PEMBAHASAN}

Andon, \& Chua,(2007) menyatakan bahwa akuntansi manajemen strategis adalah alat yang berguna untuk memberi perubahan pada manajemen guna pengambilan keputusan (Innes, \& Mitchell, 1990). Selanjutnya Penelitian Johnson, \& Kaplan (1987) menyimpulkan bahwa akuntansi manajemen strategis dikatakan berguna pada organisasi karena akuntansi manajemen strategis memberi perubahan secara flexibel pada organisasi ketika terjadi situasi yang kritis. Kemudian Alnawaiseh, (2013) menyatakan bahwa akuntansi manajemen strategis adalah alat bagi manajemen didalam suatu organisasi untuk memberi perubahan dan mengembangkan bisnis agar bisa beradaptasi dengan situasi perubahan lingkungan. Penelitian Matejka, \& De Waegenaere, (2000) menyimpulkan bahwa kegiatan perusahaan, para manajernya memproses informasi yang diberikan oleh sistem akuntansi yang terjadi guna pengambilan keputusan. Hertati \& Syafarudin. (2018) menyimpulkan bahwa manajemen perubahan adalah strategis manajemen didalam membuat suatu perubahan guna mengahdapi tantangan baru, mengadaptasi produk atau biaya serta layanan dengan nilai dengan orang lain.

Miller, \& Friesen, (1982) menyatakan bahwa manajemen perubahan adalah alat yang diberikan akuntansi manajemen strategis kepada manajer harus dapat membantu mereka dalam menentukan layanan campuran optimal yang akan diproduksi dan dijual serta keuntungan yang dihasilkan oleh setiap produk atau layanan didalam situasi yang tidak menentu guna mengambil keputusan strategis. Shank, and Vijay (1992) menimpulkan 
bahwa penerapan akunatansi manajemen strategis focus tidak terlepas dari perubahan manajemen pada biaya berbasis aktivitas dapat dilakukan secara langsung dan solid, guna mendukung proses pengambilan keputusan strategis suatu entitas. Shields \& Young (1991) fakta yang terjadi manajemen perubahan dapat memberikan informasi tentang biaya secara akurat, kepada manajer tidak hanya mengenai biaya produk/jasa atau laba yang dihasilkan, tetapi juga untuk pengambilan keputusan mengenai masalah yang dihadapi perusahaan di luar batas-batasnya, suatu fakta sangat penting dalam ekonomi kompetitif.

Ahuvia, Aaron. (2001) and Abernethy, \& Brownell, P. (1999). menyatakan bahwa manajemen perubahan didalam organisasi berfungsi sebagai strategi efektif dari penetapan biaya berdasarkan aktivitas sering kali lebih bergantung pada faktor perilaku dari pada faktor teknis, karena keterlibatan seluruh staf sangat penting untuk keberhasilan proses akuntansi manajemen. Penelitian Syafarudin. \& Hertati. (2020) .membuktikan bahwa akuntansi manajemen strategis membentuk serangkaian konsep inti akuntansi manajemen strategis di seluruh jaringan sistem. Baines, \& Langfield-Smith, (2003) menyatakan bawah konsep manajemen perubahan membentuk manajemen kerja yang baru sehingga berfungsi sebagai strategis akuntansi manajemen inti dan menguraikan perbedaan yang mencolok antara cakupan konsep-konsep tertentu di dunia antara satu dengan yang lainya menyiratkan penekanan strategis.

Simmonds (1981) and Barnett, \& Caroll, (1995 menyatakan bahwa akuntansi manajemen strategik sebagai bagian dari pengetahuan yang dikenal dengan teknik manajemen akuntansi akuntansi lingkungan bisnis dan bisnis yang kompetitif saat ini. Stewart,(1994) and Burns, \& Scapens, (1999) menyimpulkan bahwa perubahan manajemen akan, mempercepat perubahan perusahaan karena manajemen menerapkan sistem aplikasi manajemen yang taktis. Baum, and Thomas (2004) menyatakan bahwa manajemen perubahan adalah pondasinya akuntansi manajemen gunakan dengan sendirinya memberikan respons terhadap kebutuhan untuk membuktikan bukti akuntansi manajemen strategic mengadopsi dan menerapkan aplikasi di perusahaan. Yoshikawa, \& Mitchell, (1989) and Bhimani, Alnoor et,all (1999), menyatakan bahwa konsekuensi dari temuan, menyimpulkan bahwa kebutuhan stategi manajemen setuju dengan pendekatan praktik akuntansi manajemen yang baik.

Penelitian ini menjelaskan bahwa akuntansi manajemen strategic untuk mengelola organisasi secara strategis yang diikuti oleh presentasi proses biaya dalam organisasi secara sehat. Penelitian ini i menjelaskan penerapan akuntansi manajemen strategic diterapkan pada industri untuk meningkatkan kinerja organisasi dan manajemen biaya. Penelitian Smith, (1995) and Birkett, (1998) menyimpulkan bahwa panduan praktis untuk memilih teknik akuntansi manajemen didalam organisasi sangat baik. Penelitian Simmonds, (1986) and Bhimani,et,all (1992) menunjukkan bahwa penerapan akuntansi manajemen strategic adalah dapat meningkatkan kualitas informasi akuntansi yang disajikan oleh sistem penetapan biaya, dan kualitas proses yang berproses secara sehat dan baik. 
I-FINANCE: a Research Journal on Islamic Finance Vol.06 No. 02 Desember 2020 http://jurnal.radenfatah.ac.id/index.php/I-Finance

Lesi Hartati, Apriapollo Syafarudin, Otniel Safkaur...Peran Manajemen Perubahan

\section{KESIMPULAN}

Perubahan pola hidup akibat virus Corona atau Covid-19 berdampak keseriusan kesehatan masyarakat dan manajemen perubahan hidup yang mengancam stabilitas ekonomi. Beberapa perusahaan sudah melakukan efisiensi, mulai dari memotong gaji hingga memutuskan Penghentian Hubungan Kerja (PHK). Kendati dalam kondisi saat ini, ada beberapa hal yang bisa dilakukan untuk bertahan selama Covid-19. Misalnya dengan bentuk tim khusus untuk memastikan perwakilan dari tiap divisi saling berkomunikasi untuk membahas dan menentukan prioritas masalah. Akuntansi manajemen trategi didalam mendesain manajemen perubahan harus mempertimbangkan dan menyesuaikan terhadap lingkungan dan struktur organisasi, karena akuntansi manajemen strategi pada suatu organisasi kemungkinan tidak sama dengan organisasi lainnya. Akuntansi manajemen strategi secara universal tepat untuk diterapkan pada seluruh organisasi dan dalam setiap situasi agar strategi didlam usaha-usaha yang terintegrasi yang melibatkan semua pihak dalam perusahaan untuk melaksanakan perbaikan mutu pada seluruh proses bisnis perusahaan. Akuntansi manajemen strategis harus mampu mengadopsi filosofi yang mendasari konsep mengungkapkan pendapatnya tentang penggunaan desain trategi didalam menghadapi ketidakpastian alam yang akan terjadi. Akuntansi manajemen strategis didalam suatu perusahaan memiliki sumber daya manusia dengan proporsi yang dapat merancang situasi dan kondisi secara cepat dan tepat guna dapat beradaptasi dengan kondisi yang terjadi secara mendadak. Sehingga informasi yang disediakan oleh sistem akuntansi strategis dapat menekan biaya yang lebih berorientasi ke penyediaan informasi keuangan bagi pemakai luar maupun pekaian biaya didalam perusahaan dapat diminalkan. Perusahaan, dapat memprediksi situasi biaya untuk menjalankan sistem akuntansi manajemen strategis tentang biaya lebih rinci, kenyataannya melebihi manfaat yang diperoleh.

\section{REFERENCES}

[1]. Abernethy, M. A., \& Brownell, P.1999. The role of budgets in organizations facing strategic change: An exploratory study. Accounting, Organizations and Society, 24(3), 189-204.

[2]. Allen, I. E., \& Seaman, C. A. 2007. Likert scales and data analyses. Quality Progress, 40(7), 64-65.

[3]. Baines, A., \& Langfield-Smith, K. 2003. Antecedents to management accounting change: a structural equation approach. Accounting, Organizations and Society, 28(7,8), 675-698.

[4]. Andon, P., Baxter, J., \& Chua, W. F. .2007. Accounting change as relational drifting: A field study of experiments with performance measurement. Management Accounting Research, 18(2), 273-308.

[5]. Alnawaiseh, M.A.L.I.2013. Theextent of applying strategic management accounting toolsin Jordanianbanks. International Journalof Business andManagement, 8(19), 3244.

[6]. Ahuvia, Aaron. 2001, Traditional, Interpretive, and Reception Based Content Analysis: Improving the Ability of Content Analysis to Address Issues of Pragmatic and Theoretical Concern, Social Indicators Research 54, 139-172. 
[7]. Abernethy, M. A., \& Brownell, P. 1999. The role of budgets in organizations facing strategic change: An exploratory study. Accounting, Organizations and Society, 24(3), 189-204.

[8]. Baines, A., \& Langfield-Smith, K. (2003). Antecedents to management accounting change: a structural equation approach. Accounting, Organizations and Society, 28(7,8), 675-698.

[9]. Barnett, W. P., \& Caroll, G. R. 1995. Modeling internal organizational change. Annual Review of Sociology, 21, 217-236.

[10]. BPS. 2019. Gini Ratio Maret 2019 tercatat sebesar 0,382. https://www.bps.go.id/pressrelease/2019/ 07/15/1630/gini-ratio-maret-2019tercatat-sebesar-0-382.html

[11]. Burns, J., Ezzamel, M., \& Scapens, R. W. 1999. Management accounting change in the UK. Management Accounting, 77, 28-30.

[12]. Burns, J., \& Scapens, R. W. 2000. Conceptualizing management accounting change: An institutional framework. Management Accounting Research, 11(1), 3-25.

[13]. Burns, J., \& Vaivio, J. 2001. Management accounting change. Management Accounting Research, 12(4), 389-402

[14]. Baum, Heinz-Georg, Adolf G. Coenenberg, and Thomas Günther. 2004, Strategisches Controlling, $3^{\text {rd }}$ ed., Stuttgart: Schäffer-Poeschel.

[15]. Bhimani, Alnoor and Michael Bromwich. 1992. Management Accounting: evolution in progress, in Colin Drury (ed.), Management Accounting Handbook, $2^{\text {nd }}$ ed., Oxford: Butterworth Heinemann, 14-35.

[16]. Bhimani, Alnoor. 2002. European management accounting research: traditions in the making, The European Accounting Review 11, 99-117.

[17]. Bhimani, Alnoor and Mohammed H. Keshtvarz 1999, British Management Accountants: Strategically Oriented, Journal of Cost Management 13, 14-35.

[18]. Birkett, William 1998, Management accounting in Europe: a view from down-under, Management Accounting Research 9, 485-494.

[19]. Bromwich, Michael 1990, The case for strategic management accounting: the role of accounting information for strategy in competitive markets, Accounting, Organizations and Society 15, 27-46.

[20]. Burns, J., \& Vaivio, J. 2001. Management accounting change. Management Accounting Research, 12(4), 389-402.

[21]. Bromwich, Michael.1992: Strategic Management Accounting, in Colin Drury (ed.), Management Accounting Handbook, 2nd ed., Oxford: Butterworth Heinemann, 128-153.

[22]. Cadez, S., \& Guilding, C. 2008a. An exploratory investigation of an integrated contingency model of strategic management accounting. Accounting, Organizations and Society, 33(7-8), 836-863.

[23]. Cadez, S.,\&Guilding,C.2007.Benchmarking the incidence of strategic management accountingin Slovenia. Journal of Accountingand Organizational Change, 3, 126146.

[24]. Cadez, S., \& Guilding, C. (2008). An exploratory investigationofan integrated contingency model of strategic management accounting. Accounting, OrganizationsandSociety, 33(7-8), 836-863. 
[25]. Cadez, S., \& Guilding, C., 2007. Benchmarking the incidence of strategic management accounting in Slovenia. Journal of Accounting and Organizational Change, 3, 126-146.

[26]. Chenhall, R. H., \& Langfield-Smith, K. (1998a). Factors influencing the role of management accounting in the development of performance measures within organizational change programs. Management Accounting Research, 9(4), 361-386.

[27]. Chenhall, R. H., \& Langfield-Smith, K. .2003. Performance measurement and reward systems, trust, and strategic change. Journal of Management Accounting Research, 15, 117-143.

[28]. Centers for Disease Control and Prevention (CDC) di Amerika 2020.7 Fakta Penting Virus Corona Penyebab COVID-19 yang Wajib Diketahui. https://dtpeduli.org/7fakta-penting-virus-corona-penyebab-covid-19-yang-wajib-diketahui.

[29]. Chenhall, R.H., Langerfield-Smith, K. 1998 -The relationship between strategic priorities, management techniques and management accounting: an empirical investigation using a system approachl, Accounting, Organizations and Society, no.23.3.

[30]. Cravens, K.S., Guilding, C. 2001 -An empirical study of the application of strategic management accounting techniques\|, Advances in Management Accounting, no.10, pp. $95-124$.

[31]. Cravens, Karen and Chris Guilding.2001, An Empirical Study of the Application of Strategic Management Accounting Techniques, Advances in Management Accounting 10, 95-124.

[32]. Feurer, R., \& Chaharbaghi, K. (1995). Performance measurement in strategic change. Benchmarking for Quality Management \&Technology, 2(2), 64-83

[33]. Govindarajan, Vijay and John Shank.1992, Strategic Cost Management: Tailoring Controls to Strategies, Journal of Cost Management 6, 14-24.

[34]. Gomes, C. F., Yasin, M. M., \& Lisboa, J. V. 200. The dimensionality and utilization of performance measures in a manufacturing operational context: Organizational change implications. Cross Cultural Management: An International Journal, 14(4), 286-306.

[35]. Guilding, Chris, Karen Cravens, and Mike Tayles. 2000, An international comparison of strategic management accounting practices, Management Accounting Research 11, 113135.

[36]. Gurd, B., \& Thorne, H. 2003 The transformation of an accounting system during organisational change: A longitudinal study. Financial Accountability \& Management, 19(1), 21-43.

[37]. Hassan, M. K. 2005. Management accounting and organizational change: An institutional perspective. Accounting \& Organizational Change, 1(2), 125-140.

[38]. Henri, J. (2007). A quantitative assessment of the reporting of structural equation modeling information: The case of management accounting research. Journal of Accounting Literature, 26, 76-115.

[39]. Hertati.L.Syafarudin.A.2018. How the Implementation of the Industrial Revolution 4.0 Management Information System Influenced Innovation: The Case of Small and Medium Enterprises in Indonesia. Journal of Asian Business Strategy. 2018 3(4) 5262

[40]. Hertati.L, Susanto.A, Zarkasyi.W, Suharman. H, Umar.H.2019.Pengujian Empiris Bagaimana Kualitas Sistem Informasi Akuntansi Yang Dipengaruhi Oleh Etika 
Organisasi Berimplikasi Terhadap Kualitas Informasi Akuntansi (Surveypada Badan Usaha Milik Negara (Bumn) Di Sumatera Selatan Indonesia). Jurnal Ilmiah Akuntansi Rahmaniyah (JIAR) Vol. 3 No.1, Desember 2019, 88 - 107.

[41]. Hertati, L Safkaur, O, Simanjuntak. M.A. 2020.How to Align Management Commitments to the Successful Implementation of Management Accounting Information Systems in Manager Decision Making.IJTC Ilomata International Journal of Tax \& Accounting P-ISSN: 2714-9838; E-ISSN: 2714-9846

[42]. Holmes-Smith, P. (2005). Introduction to structural equation modeling using LISREL. The University of Queensland: School Research, Evaluation and Measurement Services.

[43]. Hopwood, A. G. (1990). Accounting and organization change. Accounting, Auditing \& Accountability Journal, 3(1), 7-17

[44]. Huy, Q. N. 2001. Time, temporal capability, and planned change. Academy of Management. The Academy of Management Review, 26(4), 601-623.

[45]. Hilton, R.W. 2005.Managerial accounting: creating value in a dynamic business environment, 6thedition, Boston: Mc Graw Hill.

[46]. Hutaibat, K.A.2011.Value chain for strategic management accounting in high ereducation. International Journal of Businessand Management, 6(11), 206-218.

[47]. Hoque, Z. .2001. Strategic management accounting: concepts, processes and issues, Oxford: Chandos Publishing.

[48]. Innes, J., \& Mitchell, F. 1990 The process of change in management accounting: Some field study evidence. Management Accounting Research, 1, 3-19.

[49]. Johnson, H. Thomas and Robert S. Kaplan.1987, Relevance Lost. The Rise and Fall of Management Accounting, Boston: Harvard Business School Press.

[50]. Kasurinen, Tommi.1998, Strategic Management Accounting: Review of Literature and Integrated Framework, Working Paper W-209, Helsinki School of Economics and Business Administration.

[51]. Kaplan, R. S., \& Norton, D. P., 1996. Using the balanced scorecard as a strategic management system. Harvard Business Review, 74, 75-85

[52]. Kloot, L. (1997). Organizational learning and management control systems: Responding to environmental change. Management Accounting Research, 8(1), 4773.

[53]. Lachmann, M., Knauer, T., \& Trapp, R. 2013. Strategic management accounting practicesin hospitals: Empiricalevidenceontheirdissemination under competitive emarketenvironments. Journal ofAccounting Organizational Change, 9(3), 336-369. Lukka, K.(2010).Therolesandeffectsofparadigmsinaccountingresearch. Management Accounting Research, 21, 110-115.

[54]. Laitinen, E. K. (2001). Management accounting change in small technology companies: Towards a mathematical model of the technology firm. Management Accounting Research, 12(4), 507-541

[55]. Laitinen, E. K. 2006. Explaining management accounting change: Evidence from Finland. International Journal Accounting, Auditing and Performance Evaluation, 3(2), 252-281.

[56]. Lapsley, I., \& Pallot, J. 2000. Accounting management and organizational change: A comparative study of local government. Management Accounting Research, 11(2), 213-229. 
I-FINANCE: a Research Journal on Islamic Finance Vol.06 No. 02 Desember 2020 http://jurnal.radenfatah.ac.id/index.php/I-Finance Lesi Hartati, Apriapollo Syafarudin, Otniel Safkaur...Peran Manajemen Perubahan

[57]. Lestari R.\& Hertati.L. 2020. Bagaimana Pengaruh Strategi Bisnis, Kekuatan Produk Terhadap Kualitas Sistem Informasi Akuntansi Manajemen: Studi Kasus Pada Usaha Kecil Dan Menengah Di Indonesia. KAJIAN AKUNTANSI Universitas Islam Bandung Volume 21 No. 1. Maret 2020 PP 01-16

[58]. Lord, Beverly.1996, Strategic management accounting: the emperor's new clothes?, Management Accounting Research 7, 347-366.

[59]. Luther, R., \& Longden, S. 2001. Management accounting in companies adapting structural change and volatility in transition economies: A South African study. Management Accounting Research, 12, 299-320.

[60]. Malmi, T.2010. Reflection sonpara digmsin actionin accounting research. Management Accounting Research, 21, 121-123.

[61]. Macharzina, K, Joachim W, and Anne R..2004, Quantitative Evaluation of German Research Output in Business Administration: 1992-2001, Management International Review 44, 335-359.

[62]. Matejka, M., \& De Waegenaere, A. 2000. Organizational design and management accounting change. Center for Economic Research, Tilburg University, Netherlands.

[63]. Miller, D., \& Friesen, P. H. 1982. Structural change and performance: Quantum versus piecemeal-incremental approaches. Academy of Management Journal 25(4), 867-892.

[64]. Mejer, Carsten.2004. Diffusion of Strategic Management Accounting innovations in Denmark, Working Paper, Copenhagen Business School.

[65]. Nyamori, Robert O., M. Hector Perera, and Stewart R. Lawrence.2001, The Concept of Strategic change and Implications for Management Accounting Research, Journal of Accounting Literature 20, 62-83.

[66]. OECD.2020. Stimulus UMKM di Tengah Badai Corona. https://news.detik.com/kolom/d-4974884/stimulus-umkm-di-tengah-badai-corona

[67]. Pistoni, Anna and Laura Zoni.2000, Comparative management accounting in Europe: an undergraduate education perspective, The European Accounting Review 9, 285-319.

[68]. Roslender, Robin and Susan Hart.2003, In search of strategic management accounting: theoretical and field study

[69]. perspectives, Management Accounting Research 14, 255-279

[70]. Shank, John and Vijay Govindarajan. 1992, Strategic Cost Management: The Value Chain Perspective, Journal of Management Accounting Research 4, 179-197.

[71]. Shields, M. D. \& Young, S. M., 1991 "Managing Product Life Cycle Costs: an Organizational Model", Journalof Cost Management, Fall 1, pp. 39-52.

[72]. Sulaiman, S., \& Mitchell, F. 2005. Utilising a typology of management accounting change: An empirical analysis. Management Accounting Research, 16(4), 422-437.

[73]. Sugiyono, 2013, Metode Penelitian Kuantitatif, Kualitatif dan R\&D, Cetakan Ke-19, Penerbit Alfabeta, CV. Bandung

[74]. Syafarudin.A \& Hertati.L.2020. Penerapan Human Capital, Kualitas Pelayanan Pada Sistem Informasi Manajemen. @is The Best: Accounting Information Systems and Information Technology Business Enterprise Volume 5, Nomor 1 (2020) Hal. 31-45 ISSN: 2252-9853 (Print) | ISSN: 2656-808X (Online) https://ojs.unikom.ac.id/index.php/aisthebest/index

[75]. Simmonds, K., 1981 "Strategic Management Accounting”, Management Accounting (UK), Vol. 59, No. 4, pp. 26-29. 
[76]. Simmonds, K., 1982, "Strategic Management Accounting for Pricing: A Case Example", Accounting andBusiness Research, Vol. 42, pp. 206-214.

[77]. Simmonds, K., 1986, "The Accounting Assessment of Competitive Position", European Journal of Marketing, Vol. 20, No. 1, pp. 16-31.

[78]. Simons, R., "Accounting Control Systems and Business Strategy: An Empirical Analysis", Accounting, Organizations and Society, Vol. 12, No. 4, 1987a, pp. 357374.

[79]. Simons, R., 1990, "The Role of Management Control Systems in Creating Competitive Advantage", Accounting, Organizations and Society, Vol. 15, No. 1/2, pp. 127-143.

[80]. Smith, M., 1995, Strategic Management Accounting Issues and Cases, 2nd edn (London: Butterworths, 1997). Stern, J., Stewart, G. \& Chew, D., “The EVA Financial Management System",Journal of AppliedCorporate Finance, Summer pp. 32-46.

[81]. Stewart, G., 1994, "EVA: Fact and Fantasy", Journal of Applied Corporate Finance, Summer 1994, pp. 71-84. Tani, T., Okano, H., Shimuzu, N., Fukuda, J. \& Cooray, S, "Target Cost Management in JapaneseCompanies: Current State of the Art",Management Accounting Research, Vol. 5, No. 1, pp. 67-81.

[82]. Verbeeten, F. 2010. The impact of business unit strategy, structure and technical innovativeness on change in management accounting systems. International Journal of Management, 27(1), 123-143.

[83]. Widdodo.J .2020. Virus corona: Kisah para pekerja yang tak punya hak kerja dari rumah, 'kalau belum meninggal diminta terus kerja' https://www.bbc.com/indonesia/indonesia-52018257

[84]. Yoshikawa, T., Innes, J. \& Mitchell, E., 1989, “Cost Management Through Functional Analysis”, Journal of CostManagement, Spring pp. 14-19 